\title{
Improving Class V Students' Indonesian Language Learning Outcomes Using the TPACK Approach
}

\section{Ani Kusbandiyah}

SDN 1 Sidabowa

ani.kusbandiyah@gmail.com

\section{Article History}

accepted $14 / 11 / 2020$

approved 21/11/2020

published 26/11/2020

\begin{abstract}
The purpose of this study was to improve the learning outcomes of students in the Indonesian language muple in grade $V$ elementary school writing rhymes with the TPACK approach. The research conducted was a Classroom Action Research (CAR) in three cycles, with each cycle consisting of one meeting. The stages of each cycle are planning, implementing, observing and reflecting. Each meeting was conducted with a post test to determine the development of students. In the first cycle, students who completed the post test were $78 \%$. In the second cycle, students who completed the post test were $89 \%$. In cycle III the students who completed after carrying out the post test were 100\%. These results indicate that the TPACK approach can improve student learning outcomes, especially the Indonesian language muple, the material of writing rhymes for Class $V$ at SDN 1 Sidabowa.
\end{abstract}

Keywords: learning outcomes, tpack, writing rhymes

\section{Abstrak}

Tujuan dari penelitian ini adalah untuk meningkatkan hasil belajar peserta didik pada mupel Bahasa Indonesia di sekolah dasar kelas $\mathrm{V}$ materi menulis pantun dengan pendekatan TPACK. Penelitian yang dilakukan adalah Penelitian Tindakan Kelas (PTK) sebanyak tiga siklus, dengan setiap siklusnya terdiri dari satu pertemuan. Tahapan setiap siklusnya adalah perencanaan, pelaksanaan, observasi dan refleksi. Setiap pertemuan dilakukan post test untuk mengetahui perkembangan peserta didik. Pada siklus I peserta didik yang tuntas setelah melaksanakan post test sebesar $78 \%$. Pada siklus II peserta didik yang tuntas setelah melaksanakan post test sebesar $89 \%$. Pada siklus III peserta didik yang tuntas setelah melaksanakan post test sebesar $100 \%$. Hasil ini menunjukan bahwa pendekatan TPACK dapat meningkatkan hasil belajar peserta didik khususnya mupel Bahasa Indonesia materi menulis pantun Kelas V di SDN 1 Sidabowa

Kata kunci: hasil belajar, tpack, menulis pantun

Social, Humanities, and Education Studies (SHEs): Conference Series https://jurnal.uns.ac.id/shes 


\section{PENDAHULUAN}

Pendidikan menjadi fondasi terkuat yang dapat digunakan untuk meningkatkan kualitas peserta didik agar memiliki kecakapan dan keterampilan abad XXI. Tantangan dunia pendidikan pada abad XXI ialah pendidikan hendaknya dilaksanakan agar mampu menciptakan generasi-generasi unggul yang memiliki keterampilan abad XXI. Menurut Ariyana, dkk. (2018: 14) keterampilan abad XXI yang harus dimiliki peserta didik atau yang dikenal dengan istilah 4C yakni kreatif dan inovatif (creative and innovative), kolaborasi (collaboration), berpikir kritis dan pemecahan masalah (critical thinkink and problem solving), dan komunikasi (communication).

Di sisi lain perlu diketahui bahwa cara belajar dan tingkat pemahaman peserta didik sangat beragam. Ada yang mampu memahami pelajaran dengan mudah dan cepat menanggapinya, namun ada peserta didik yang juga sangat lamban dalam memahami materi pembelajaran. Tugas dan tanggungjawab guru sebagai pendidik adalah membantu dan membimbing peserta didik untuk mencapai kedewasaan seluruh ranah kejiwaan sesuai dengan kriteria yang telah ditetapkan. Oleh karena itu, untuk menjalankan tugas dan tanggungjawab tersebut guru berkewajiban merealisasikan segenap upaya yang mengarah kepada pengertian yang lebih mendalam lagi, sehingga mencapai tujuan pembelajaran. Sedangkan untuk menghadapi perkembangan zaman, penggunaan teknologi menjadi suatu keniscayaan dalam proses pembelajaran. Pada era modernisasi seorang guru dituntut untuk bisa menguasai teknologi. Pembelajaran di masa Pandemi saat ini mengharuskan pembelajaran dilakukan dengan jarak jauh atau yang sering disebut dengan istilah pembelajaran daring. Penguasaan pengetahuan dan keterampilan teknologi menjadi wajib bagi guru untuk mewujudkan tujuan pembelajaran. Namun teknologi saja tentu tidak bisa mengatasi problematika yang dihadapi dan terus berkembang.

Perpaduan antar beberapa komponen menjadi salah satu alternatif solusi pendekatan pembelajaran sebagai jawaban atas persoalan yang sudah kompleks, salah satunya adalah pendekatan TPACK. Menurut Mishra, et al (2016: 2) TPACK adalah suatu kerangka kerja untuk memahami dan menggambarkan jenis pengetahuan yang dibutuhkan oleh seorang guru untuk mengefektifkan praktek pedagogi dan pemahaman konsep dengan mengintegrasikan sebuah teknologi di lingkungan pembelajaran.

Menurut Sujana (2009: 3) hasil belajar peserta didik pada hakekatnya adalah perubahan tingkah laku. Tingkah laku sebagai hasil belajar dalam pengertian yang luas mencakup bidang kognitif, afektif dan psikomotoris. Selain perubahan tingkah laku, jika di sekolah hasil belajar biasanya dinilai dengan angka. Peserta didik akan mendapat nilai yang akan menggambarkan keberhasilan dalam belajar.

Berdasarkan data hasil belajar yang didapatkan oleh peserta didk pada muatan pelajaran Bahasa Indonesia ditemukan masih rendah. Hal tersebut dilihat dari nilai Pra Siklus peserta didik kelas V tahun ajaran 2020/2021 yang diambil pada muatan pelajaran Bahasa Indonesia. Dari jumlah total peserta didik di kelas $\mathrm{V}$ sebanyak 18 orang dengan KKM 70, ada 9 peserta didik yang mendapat nilai di bawah KKM dan ada 9 peserta didik yang mencapai nilai KKM. Itu berarti ada 50\% peserta didik yang belum mencapai KKM dan ada $50 \%$ peserta didik yang sudah mencapai KKM.

\section{METODE}

Penelitian ini adalah penelitian tindakan kelas (Classroom Action Research) dengan menerapkan model pembelajaran Project Based Learning (PjBL). Menurut Kurt Lewin dalam Kunandar (2011: 42) penelitian tindakan kelas ini terdiri dari empat tahapan dasar yaitu perencanaan (planning), pelaksanaan (acting), 
pengamatan (observing) dan refleksi (reflecting). Analisis penelitian ini adalah analisis deskriptif kuantitafif kualitatif dimana dalam penelitian ini selain penyajian hasil berupa data maupun angka peneliti juga menentukan bagaimana cara pengolahan hasil penelitian yakni dengan membuat analisisnya dengan menerapkan pendekatan TPACK. Penelitian ini dilaksanakan pada peserta didik kelas V SDN 1 Sidabowa Tahun Pelajaran 2020/2021 selama tiga siklus secara daring menggunakan aplikasi zoom dengan satu pertemuan di setiap siklusnya. Siklus I dilaksanakan pada tanggal 2 November 2020. Siklus II dilaksanakan pada tanggal 9 November 2020. Siklus III dilaksanakan pada tanggal 20 November 2020. Teknik pengumpulan data yang dilakukan dengan observasi dan post test. Observasi meliputi observasi keterlaksanaan pendekatan TPACK, sikap peserta didik dan keterampilan. Untuk hasil belajar menggunakan tes melalui Google form.

\section{HASIL DAN PEMBAHASAN}

Hasil penelitian menunjukkan peningkatan hasil belajar pada materi menulis pantun. Terlihat pada tabel berikut.

Tabel 1. Rekapitulasi Hasil Tes Akhir Peserta didik

\begin{tabular}{cccccc}
\hline No & Range Nilai & $\begin{array}{c}\text { Jumlah } \\
\text { Peserta } \\
\text { didik } \\
\text { Prasiklus }\end{array}$ & $\begin{array}{c}\text { Jumlah } \\
\text { Peserta } \\
\text { didik } \\
\text { Siklus I }\end{array}$ & $\begin{array}{c}\text { Jumlah } \\
\text { Peserta } \\
\text { didik } \\
\text { Siklus II }\end{array}$ & $\begin{array}{c}\text { Jumlah } \\
\text { Peserta } \\
\text { didik } \\
\text { Siklus III }\end{array}$ \\
\hline 1. & $81-100$ & 0 & 0 & 7 & 16 \\
2. & $61-80$ & 12 & 14 & 9 & 2 \\
3. & $41-60$ & 3 & 2 & 1 & 0 \\
4. & $21-40$ & 1 & 1 & 1 & 0 \\
5. & $0-20$ & 2 & 1 & 0 & 0
\end{tabular}

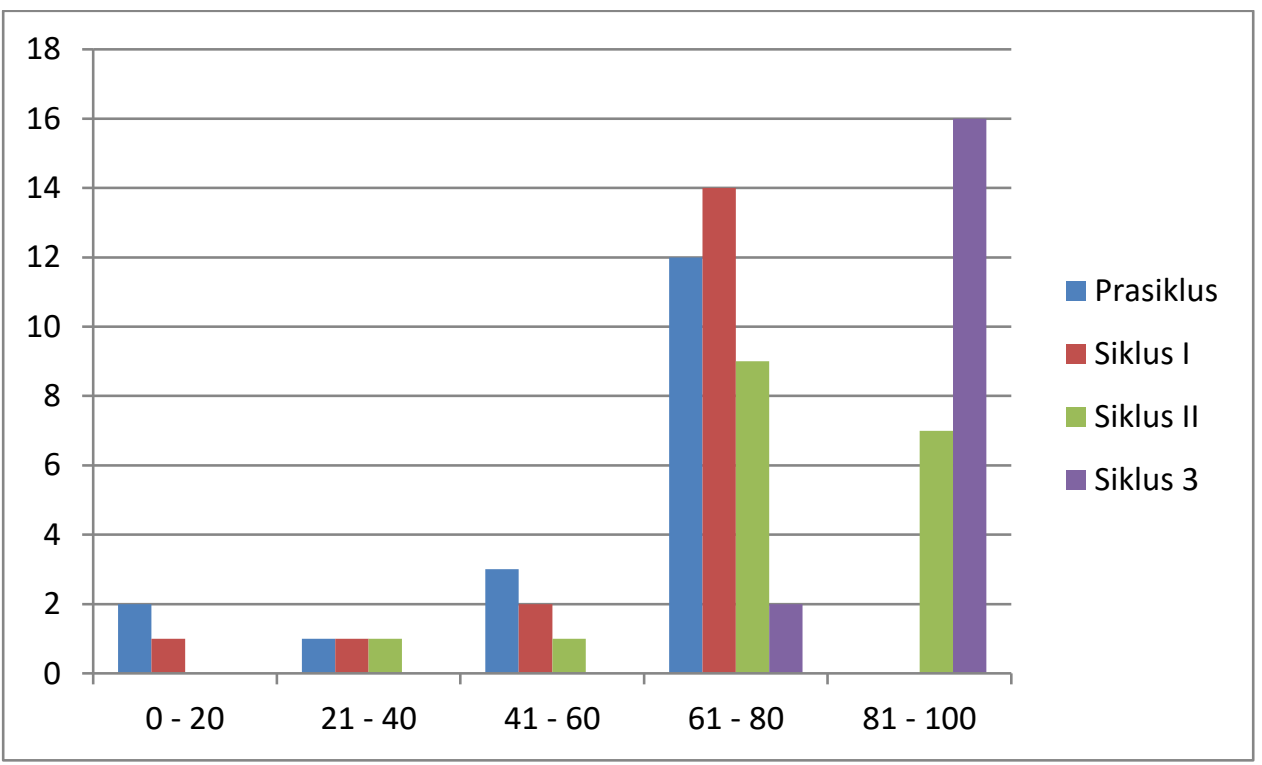

Diagram 1. Rekapitulasi Hasil Tes Akhir Peserta didik

Peningkatan hasil belajar Bahasa Indonesia pada materi menulis pantun diukur dengan menggunakan teknik tes hasil belajar dengan instrumen lembar soal evaluasi. 
Teknik pengumpulan data hasil belajar peserta didik diterapkan di setiap pertemuan setelah dilakukan kegiatan pembelajaran.

Penggunaan pendekatan TPACK dalam pembelajaran Bahasa Indonesia dapat meningkatkan hasil belajar peserta didik di kelas V SDN 1 Sidabowa. Pada hasil penilaian sebelumnya persentase ketuntasan belajar hanya $50 \%$. Setelah dilakukan tindakan, persentase ketuntasan belajar meningkat menjadi $78 \%$. Pada siklus II terjadi peningkatan kembali yang mencapai $89 \%$. Setelah melakukan refleksi pada siklus II, maka diputuskan untuk melanjutkan pada siklus III. Hal ini dilakukan agar mengetahui sejauh mana penerapan pendekatan TPACK tidak hanya meningkatkan tetapi juga mempertahankan hasil belajar peserta didik. Hasil belajar peserta didik dapat dilihat pada tabel berikut. Pada siklus III terjadi peningkatan kembali yang mencapai $100 \%$ dengan KKM 70.

Berdasarkan tabel hasil belajar peserta didik terhadap penggunaan pendekatan TPACK dapat dilihat bahwasanya peserta didik sangat tertarik untuk menggunakan pendekatan TPACK dalam pembelajarannya. (Luqman et al., 2017) menyatakan bahwa pembelajaran yang menyenangkan, menarik minat dan tidak membosankan peserta didik, salah satu awal agar pembelajaran menjadi bermakna yang pada akhirnya dapat meningkatkan hasil belajar peserta didik.

\section{SIMPULAN}

Penggunaan pendekatan TPACK dalam pembelajaran menulis pantun sangat memotivasi peserta didik dalam belajar. Pendekatan TPACK dapat menarik minat dan keaktifan peserta didik dalam kegiatan pembelajaran. Hal ini sangat berpengaruh terhadap peningkatan hasil belajar peserta didik yang dengan ketuntasan hasil belajar peserta didik pada siklus I sebesar $78 \%$, meningkat menjadi $89 \%$ pada siklus II, dan meningkat menjadi $100 \%$ pada siklus III.

Berdasarkan hasil penelitian tindakan kelas tersebut, guru dapat melibatkan peserta didik dalam pemanfaatan kemajuan teknologi dengan bantuan pendekatan TPACK agar peserta didik lebih menguasai materi pembelajaran, sehingga hasil belajarnya meningkat. Sekolah hendaknya memotivasi guru untuk terus berusaha memanfaatkan teknologi dalam kegiatan pembelajaran yang berdampak pada peningkatan hasil belajar peserta didik.

\section{DAFTAR PUSTAKA}

Arikunto, S., Suhardjono, Supardi. (2010). Penelitian Tindakan Kelas. Jakarta: Bumi Aksara. Kemmis, S. \& McTaggart, R. (1997). The action research planner, Deaken University,

Desmita (eds), 2009. Psikologi Perkembangan. Bandung: PT Remaja Rosdakarya

Mohammad Asrori. 2009. Penelitian Tindakan Kelas. Bandung : CV Wacana Prima.

Moh. Nazir, (1991). Metode Penelitian. Jakarta

Mulyasa (eds), 2009. Praktik Penelitian Tindakan Kelas. Bandung: PT Remaja Rosdakarya.

Rochniati Wiraatmaja (eds), 2009. Metode Penelitian Tindakan Kelas. Bandung: PT Remaja Rosdakarya Offset.

Slameto. 2010. Belajar Dan Faktor-faktor Yang Mempengaruhinya. Jakarta : Rineka cipta). Edisi revisi

Sumiati, Asra. 2009. Metode Pembelajaran. Bandung: CV Wacana Prima. Sukardi (eds). 2011. Metodologi Penelitian Pendidikan. Jakarta: PT Bumi Aksara.

Sukidin, Basrowi \& Suranto (eds). 2010. Manajemen Penelitian Tindakan Kelas. Insan Cendekia.

https://wahyutrilestari.com/tpackmateri.html\#: :text=Menurut\%20Mishra\%2C\%20et\%2 0al\%20(2016,sebuah\%20teknologi\%20di\%20lingkungan\%20pembelajaran 